\title{
Isolation and Molecular Characterization of Pesticide (Fenitrothion) Resistant Bacteria from Agricultural Field
}

\author{
M. A. Akhter ${ }^{1}$, R. Laz ${ }^{2}$ \\ ${ }^{I}$ (Department of Zoology, Kurigram Govt. Woman's College, Kurigram, Bangladesh) \\ ${ }^{2}$ (Department of Zoology, University of Rajshahi, Rajshahi, Bangladesh)
}

\begin{abstract}
Elimination of pollutants from contaminated sites using microorganisms is a cheaper alternative to chemical technology. There is therefore a need to isolate, identify and characterize the microorganisms that exist and interact in contaminated environment and to isolate the genetic determinants of resistance, frequently located on plasmids and transposons. Investigations were carried out to isolate microbial strains from the fenitrothion polluted soil. Bacteria were isolated using enrichment culture technique containing fenitrothion as sole source of carbon and energy was isolated in pure culture and selected for their ability to degrade fenitrothion. Growth curve experiments showed that the bacterial consortium was able to grow in mineral medium containing fenitrothion as the only carbon source. The microorganisms were identified as Bascillus sp. The identity of the isolate was determined through biochemical and morphological characteristics. For more confirmation, 16s rRNA gene analysis was done using PCR with universal primers. Comparative analysis of the 16s rRNA gene sequences in the Gene Bank database revealed that this bacteria was related to the genus Basicllus substilis. The bacterial strains were found to harbor endogenous plasmids.
\end{abstract}

KEYWORDS- Bacteria, Biochemical characters, Fenitrothion, Gene sequencing

\section{INTRODUCTION}

The ecosystem is contaminated by indiscriminate and wide spread use of pesticides in controlling the agricultural pests. The increasing chemization in all areas of man's activities has inedible impact also besides its benefits. Though they have contributed considerably to agricultural outcomes, their accumulation in the environment is adversely affect the environment (1).The microbial degradation of hazardous waste offers apromising strategy by which such chemicals may safely be detoxified. For that reason there is a need to isolate, identify and distinguish the microorganisms that subsist interact in contaminated environment and to isolate the genetic determinants of resistance, frequently located on plasmids and transposons $(2,3,4 \& 5)$. The present study described the isolation and genetic characterization of the pesticide (fenitrothion) resistant bacterial stain which was isolated from the fenitrothion contaminated soil.

\section{MATERIALS AND METHODS}

\subsection{Collection and enrichment of fenitrothion degrading bacteria}

Fenitrothion degrading bacteria were isolated by enrichment culture techniques using an inoculum of fenitrothion treated soil collected from agricultural fields with histories of application. 10g soil was suspended in sterilized distilled water and its diluted suspensions were inoculated in $250 \mathrm{ml}$ Erlenmeyer flasks with $100 \mathrm{ml}$ minimal medium at the temperature of $28^{\circ} \mathrm{C}$ for $24 \mathrm{~h}$, and microbial density determined spectrophotometrically $(600 \mathrm{~nm})$. To isolate fenitrothion resistant bacteria, $1 \mathrm{ml}$ of microbial suspension was spread on minimal medium containing fenitrothion. Control flask without an inoculum was also prepared to take account of any abiotic disappearance of the fenitrothion. After incubation at $28^{\circ} \mathrm{C}$ for $24 \mathrm{~h}$, with shaking at $120 \mathrm{rpm}$ on an orbital shaker, which were found to be turbed were used as inoculums in subsequent experiments.

\subsection{Pure culture preparation}

Bacterial pure culture was prepared by streak plate method (6). One loop full of enrichment culture from the flasks were streaked on minimal medium suplimented with fenitrothion. The growth of the bacterial colonies was measured after $24-48 \mathrm{~h}$ incubation at $28^{\circ} \mathrm{C}$. Morphologically dissimilar colonies were randomly selected and sub cultured onto minimal medium and maintained at $4^{\circ} \mathrm{C}$ for bacterial characterization $(7,8 \& 9)$. Minimal medium were prepared by dissolving $2.0 \mathrm{~g}$ of Dipotassium hydrogen phosphate, $0.05 \mathrm{~g}$ of Magnesium sulphate $\left(\mathrm{MgSO}_{4}\right), 0.2 \mathrm{~g}$ of Potassium dihydrogen phosphate, $\left(\mathrm{KH}_{2} \mathrm{PO}_{4}\right), 0.5 \mathrm{~g}$ of Ammonium sulphate, $\left(\mathrm{NH}_{4}\right)_{2} \mathrm{SO}_{4}$ and $1 \mathrm{ml}$ of Trace elements (Stock solution) in 1 liter distilled water and measured the pH.7.2 . After then medium was autoclaved at $121^{\circ} \mathrm{C}$ for $1 \mathrm{~h}$. Stock solution of fenitrothion was added to minimal medium after sterilization to obtain the desired concentration. 


\subsection{Screening of the bacterial stains with pesticide tolerance}

To monitor the bacterial ability to tolerance to pesticide, isolated colonies were picked up and striked on minimal medium with successively higher concentrations $(10,20 \& 30 \mu \mathrm{g})$ of fenitrothion. The stains capable of growing under this condition were selected for further experiment ( $\mathrm{pH}$ and temperature).

\subsection{Growth kinetic studies}

Inoculum was prepared by taking a loop full of the bacterial culture from the preserved slant inoculated into $10 \mathrm{ml} \mathrm{MS}$ broth tube and incubated at $30^{\circ} \mathrm{C}$ for $24 \mathrm{~h}$. For growth kinetic studies $1 \mathrm{ml}$ of $24 \mathrm{~h}$ old culture was inoculated into $100 \mathrm{ml}$ of minimal medium broth flask and were adjusted in different $p H$ and incubated in different temperature, because temperature and $p H$ influenced the bacterial growth. For the effect of $p H$, culture medium was adjusted to $p H 5.0,6.0,7.0$ and 8.0. Incubation temperature was varied at $25,30,37$ and $45^{\circ} \mathrm{C}$. Bacterial cell density of liquid culture were determined by measuring optical density at $660 \mathrm{~nm}$ with photoelectric colorimeter (AE-11M, ERMA INC, TOKYO).

\subsection{Morphological and biochemical characteristics of the isolates}

Pure bacteria isolated from arable soil were tested for Gram character, morphology, motility, catalase test, oxidase reactions, citrate utilization, indole production, methyl red, sodium chloride tolarance test coagulase test, etc. $(10,11,12 \& 13)$. Bergey's manual of determinative of bacteriology was used as a reference to identify the isolates (14). The identity of the isolate was however confirmed through molecular characterization.

\subsection{Plasmid profile screening}

Plasmid DNA was isolated from selected stains using Birnboin \& Doly method and Kudo \& Liu method also (15 \&16) and visualized in $1 \%$ agarose gell under the ultraviolet illumination. Ethidium bromide was used to stain the gel.

\subsection{Characterization of isolated bacteria by 16s $r$ RNA gene analysis}

The extraction of chromosomal DNA was done according to Sambrook et al. (17).

\subsubsection{PCR amplification of the 16s rRNA Gene}

Gene fragments specific for the highly variable region of the bacterial 16s rRNA gene was amplified by PCR as described by Loffler et al. (18). This reaction was carried out by the universal primer $16 \mathrm{~s}$ forward \& $16 \mathrm{~s}$ reverse (Sigma USA). The primer sequences were as follows: 5'- GAGTTTGATCCTGGCTCAG -3' forward primer and 5'- GAAAGGAGGTGATCCAGCC -3' reverse primer (18).All PCR reagents were used from the invitrogen. PCR is performed in a $50 \mu \mathrm{l}$ reaction mixture containing $5 \mu 1$ of $10 \mathrm{X}$ PCR buffer, $4 \mu 1$ of $2.5 \mathrm{mM}$ dNTPs, $2 \mu \mathrm{l}$ of $50 \mathrm{mM} \mathrm{MgCl}_{2}, 2.5 \mu \mathrm{l}$ of each primer $(10 \mu \mathrm{lM}), 0.2 \mu \mathrm{l}$ of $5 \mathrm{U} / \mu \mathrm{l}$ tag DNA polymerase, $3 \mu 1$ genomic DNA and rest of the PCR water.As a PCR program an intial denaturation step at $95^{\circ} \mathrm{C}$ for $5 \mathrm{~min}$. followed by 30 cycles of denaturation at $94^{\circ} \mathrm{C}$ for $1 \mathrm{~min}$. primer annealing at $55^{\circ} \mathrm{C}$ for $1 \mathrm{~min}, 1 \mathrm{~min}$. of primer extension at $72^{\circ} \mathrm{C}$ and $10 \mathrm{~min}$. of finalextantionat $72^{\circ} \mathrm{C}$ for one cycle. Amplicons were separated by agarose gel electrophoresis $(1 \%)$ in $0.5 \mathrm{X}$ Tris/borate/EDTA buffer. Products were stained with ethidium bromide, destined with distilled water, and visualized under UV light and photographed on a gel-documentation system. 1500bp PCR products are obtained. $1 \mathrm{~kb}+$ DNA size markers (invitrogen, USA) were used to determine the size of the PCR product.

\subsubsection{Purification of the PCR products}

For purification the PCR product was cut from the gel and purified by using commercially available Microcon Centrifugal Filter device, USA. The desired band was cut from the DNA gel Extraction Spin Columns. Then partial purified sample reservoir was inserted into screw cap vial. The entire solution (PCR product) was pipetted into sample reservoir $(0.5 \mathrm{ml}$ maximum volume), without touching the membrane with the pipette tip. The attached cap of screw cap vial was then sealed. The assembly (screw cap vial with sample reservoir) was placed in a centrifuge machine. When placing the assembled device into the centrifuge rotor, the cap strap was aligned toward the centre of the rotor. The assembly was spin at $14000 \mathrm{rcf}$ for $20 \mathrm{~min}$. The assembly was then removed from the machine and vial is separated from the sample reservoir. The sample reservoir was placed upside down in a new vial, and then spin at 1000 rcf for $3 \mathrm{~min}$. to transfer the concentrate to

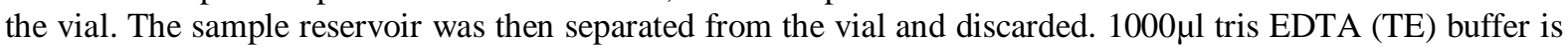
added to the vial containing the purified PCR product. Concentration of the PCR product was measured using UV spectrophotometer and diluted to $10 \mu \mathrm{g} / \mu \mathrm{l}$ with TE buffer. 


\subsubsection{Cycle sequencing}

The primer was diluted to $3.2 \mu \mathrm{M}$ using PCR water. The reagents $[4 \mu \mathrm{l}$ of Big dye reaction mixture, $1 \mu \mathrm{l}$ of template $(10 \mu \mathrm{g} / \mu \mathrm{l}), 1 \mu \mathrm{l}$ of Primer $3.2 \mu \mathrm{M}, 14 \mu \mathrm{l}$ of PCR water] added to a separate tube for each reaction. After mixed well and spin briefly the tubes were placed in a thermal cycler (Applied Biosystem 9700, USA). The sample was then stored at $4^{\circ} \mathrm{C}$ and hold at this temperature until ready to purify. The cycle sequencing programs are shown in Table 1.

TABLE 1. Cycle sequencing program

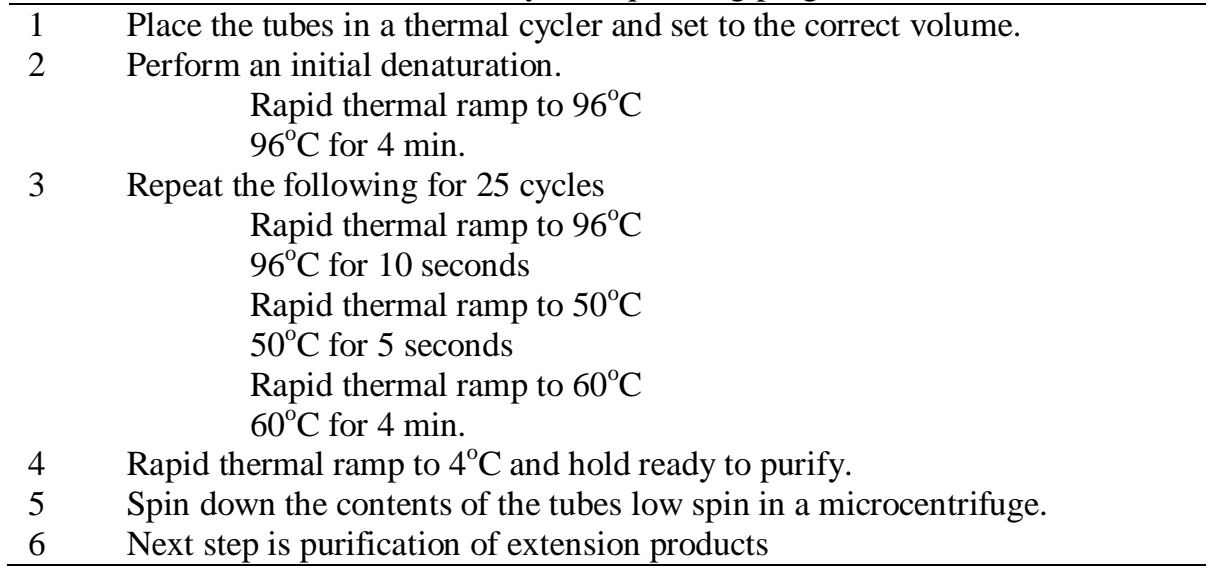

For purification of the cycle sequence product use applied bio system 9700 series or similar machine 2.15 and detection of Nucleotides by ABI-PRISM 310 (Table 2).

TABLE 2. Purification of the cycle sequence product

\begin{tabular}{llll}
\hline Step & Temperature $\left({ }^{\circ} \mathrm{C}\right)$ & Time $(\min )$. & No. of cycle \\
\hline Initial denaturation & 96 & 5 & 1 \\
Denaturation & 96 & 10 & 25 \\
Annealing & 50 & 5 & 25 \\
Extension & 60 & 4 & 25 \\
Final extension & 60 & 1 & 1 \\
\hline
\end{tabular}

The entire content of each reaction was transferred to a tube where $2 \mu \mathrm{l}$ of $3 \mathrm{M}$ sodium acetate $(p H 4.6)$ and $50 \mu \mathrm{l}$ of $95 \%$ ethanol were placed and then they are mixed thoroughly. The tubes were then incubated at room temperature for more than $15 \mathrm{~min}$. to precipitate, then centrifuged at $13,000 \mathrm{rpm}$ for $20 \mathrm{~min}$. The pellet were washed with $250 \mu \mathrm{l}$ of $70 \%$ ethanol by washing the walls of the tubes. The tubes were spin at 13,000 rpm for 10 min. The washing steps were repeated twice. The pellet was dried by keeping the caps of the tubes opened for 2$3 \mathrm{~h}$ at room temperature. The opened tubes were covered by parafilm. The pellet was then re suspended into foramaide and mixed well. Then it was heated at $95^{\circ} \mathrm{C}$ for $2 \mathrm{~min}$. and immediately transferred into ice and kept for $5 \mathrm{~min}$. then the products were transferred to septal tube.

\subsubsection{Detection of the nucleotide by ABI-PRISM 310}

The purified cycle sequence products were analyzed by electrophoresis in the genetic analyzer (Prism 310, USA). DNA is separated through the POP6 contained in the capillary and detected by the laser beam. When the nucleotides reach a detector window in capillary electrophoresis, the fluorescent labeled fragments were excited by the laser beam of the machine. The laser excites the fluorescent dye labels and emitted fluorescence was collected by CCD camera. The fluorescence intensity data is interpreted into sequence data by specific bioinformatics software.

\subsubsection{Sequence analysis}

The sequences were then edited by bioinformatics software Chromas. The homology of the 16S rRNA gene sequences was checked with the 16S rRNA gene sequences of other organisms that had already been submitted to Gene Bank database using the BLASTN (http:/www.ncbi.nih.gov/BLAST) algorithm.

\section{RESULT}

Investigations were focused on to the isolation and characterization of the arobic bacterial stains with pesticide (fenitrothion) tolerance to identify potential candidates for fenitrothion bioremediation. Three (two of 
them are not described) different types of colonies in abundance were observed on minimal medium amended with fenitrothion.

\subsection{Isolation of fenitrothion resistant bacteria}

The enrichment procedure generated a pure culture that was able to grow on fenitrothion as a sole source of carbon. Isolate was rod-shaped, Gram-positive (Fig. $1 \& 2$ ).

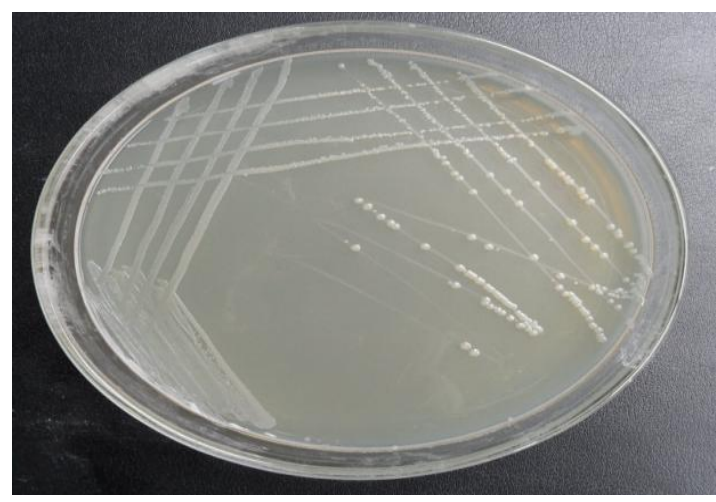

FIGURE 1. Isolated bacterial colonies

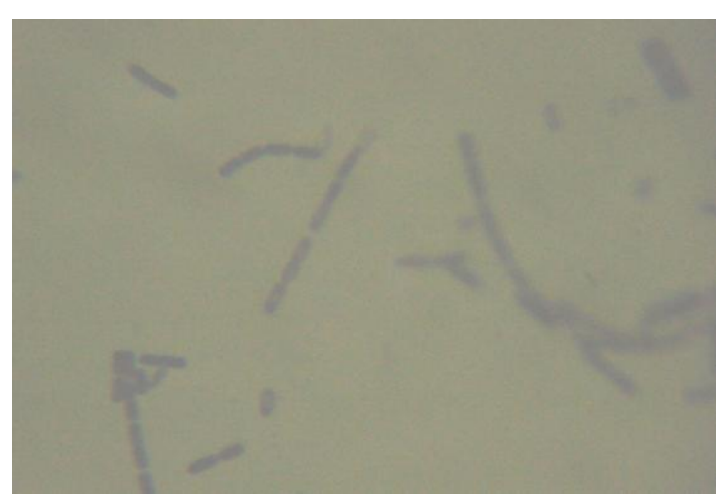

FIGURE 2. Microscopic view of isolated bacteria

\subsection{Biochemical characterization of pesticide degrading bacteria}

After treatment with fenitrothion the bacterial strain isolates were abundant in culture medium was identified as fenitrothion degraders. The bacterial isolates were morphologically and biochemically typified and properties were listed in Table 3.

TABLE 3. Biochemical characters of bacteria

\begin{tabular}{|c|c|c|c|c|c|}
\hline \multirow{22}{*}{ 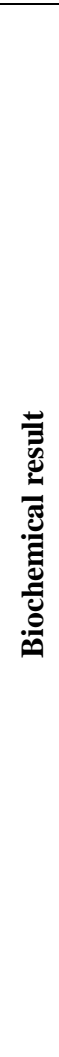 } & Test & Result & \multirow{13}{*}{ 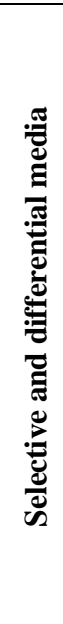 } & Test & Result \\
\hline & Citrate & + & & Listeria oxfrod & - \\
\hline & Lysine iron agar & - & & BPA & - \\
\hline & Triple suger iron agar & $\mathrm{y} / \mathrm{y}$, gas & & SSA & Yellowish \\
\hline & Arginine decarboxylase & Yellow, growth & & XLD & Yellowish \\
\hline & Rhamnose & + & & BSA & Black \\
\hline & Lactose & - & & PALCAM & - \\
\hline & Dextrose & - & & Mac conkey agar & Offwhite, reddish \\
\hline & Mannitol & + & & DNAse test & - \\
\hline & Xylose & + & & Cetrimide agar & + \\
\hline & Sucrose & + & & PEMBA & - \\
\hline & Anaerobic dextrose & + & & TCBS & yellow \\
\hline & Motility (Sim) & - & & Pseudomonas agar & \\
\hline & Anaerobic mannitol & + & & & \\
\hline & $2 \% \mathrm{NaCl}$ & + & & & \\
\hline & Arginine decomposition & - & & & \\
\hline & Indole & - & & & \\
\hline & Nitrate & + & & & \\
\hline & Methyl red & - & & & \\
\hline & Voges proskauer & - & & & \\
\hline & Oxidase & - & & & \\
\hline & catalase & - & & & \\
\hline
\end{tabular}




\subsection{Growth kinetic study of isolates in nutrient broth}

It is seen from figure 3 and 4 that the phase of acclimation of isolets continued up to almost $4 \mathrm{~h}$ after the initial inoculation in minimal medium. The culture entered the log phase after $4 \mathrm{~h}$ of incubation and remained in that phase during $24 \mathrm{~h}$.

The optimum temperature $30^{\circ} \mathrm{C}$ and $37^{\circ} \mathrm{C}$ for the growth of bacteria and extreme temperature $45^{\circ} \mathrm{C}$ and $25^{\circ} \mathrm{C}$ restricted to the bacterial growth.

The optimum $p H$ for the growth of the isolates were $7.0 \& 8.0$ and extreme $p H 5.0$ and 6.0 restricted to the bacterial growth.

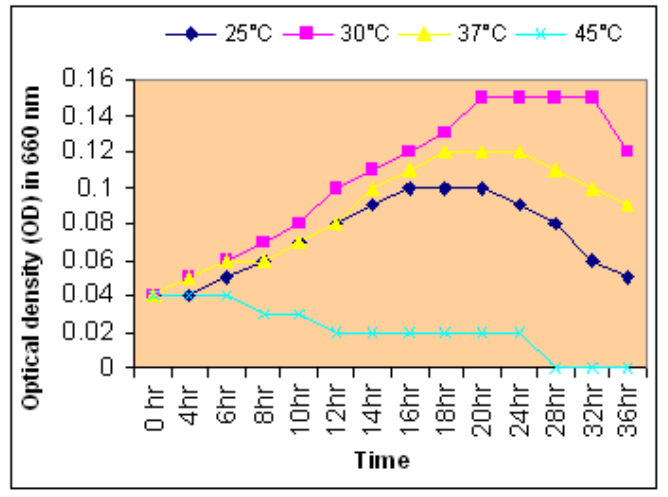

FIGURE 3. Effects of temperature on bacterial growth

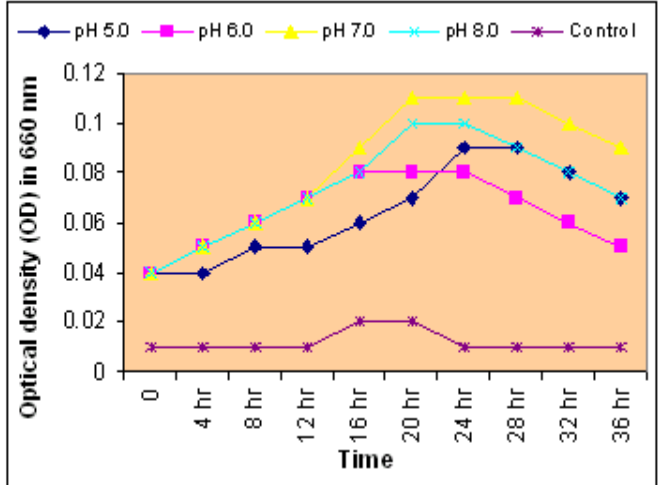

FIGURE 4. Effects of $p H$ on bacterial growth

\subsection{Extraction of Chromosomal DNA}

There was 1 band of Chromosomal DNA was found the agarose gel after illumination with the UV light. The $1 \mathrm{~kb}+$ DNA marker was used for size determination. Lane one indicates the DNA marker and lane 2 indicates the bacterial chromosomal DNA. The isolated chromosomal DNA was $1500 \mathrm{bp}$ which compared with $1 \mathrm{~kb}+$ DNA marker (Fig. 5).

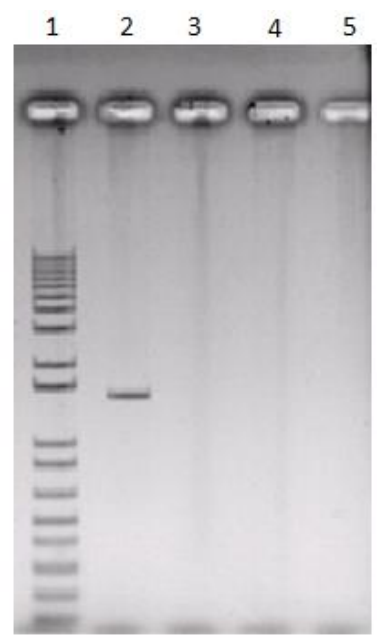

FIGURE 5. PCR Amplification of $16 \mathrm{~S}$ rRNA gene yielded a $1500 \mathrm{bp}$ PCR product, $1 \mathrm{~kb}+\mathrm{DNA}$ marker is used for size determination

\subsection{Identification of bacteria By DNA sequencing \\ 3.5.1 Sequence exported from chromatogram file}

Sequencing of the 16S rRNA gene and comparison with previously published 16S rRNA gene sequences resulted in the classification of the isolate as a member of the genus Bascillus. 
CCAAGGCAACGATGCGTAGCCGACCTGAGAGGGTGATCGGCCACACTGGGACTGAGACAC GGCCCAGACTCCTACGGGAGGCAGCAGTAGGGAATCTTCCGCAATGGACGAAAGTCTGAC GGAGCAACGCCGCGTGAGTGATGAAGGTTTTCGGATCGTAAAGCTCTGTTGTTAGGGAAG AACAAGTACCGTTCGAATAGGGCGGTACCTTGACGGTACCTAACCAGAAAGCCACGGCTA ACTACGTGCCAGCAGCCGCGGTAATACGTAGGTGGCAAGCGTTGTCCGGAATTATTGGGC GTAAAGGGCTCGCAGGCGGTTTCTTAAGTCTGATGTGAAAGCCCCCGGCTCACCCGGGGA GGGTCATTGGAAACTGGGGAACTTGAGTGCAGAAGAGGAGAGTGGAATTCCACGTGTAGC GGTGAATGCGTANAGATGTGGAAGAACACCAGTGGCGAANGCGACTCTCTGGTCTGTAAC TGANGCTGANGANCGAAAGCGTGGGGAGCGAACAGGATTAGATACCTGGTAGTCCCGCCG TAACGATGANGNTAAGNGTAGGGG

\subsubsection{DNA sequencing analysis of $16 \mathrm{~S}$ rRNA gene}

After the 16S rRNA gene sequencing and editing of sequences it was checked with the 16S rRNA gene sequences of other organisms that had already been submitted to Gene Bank database. The highest degree of similarity found was 97\%, which was the value obtained with the 16S rRNA gene of Bascillus substilis. Based on these observations, the isotate was identified as Bascillus substilies.

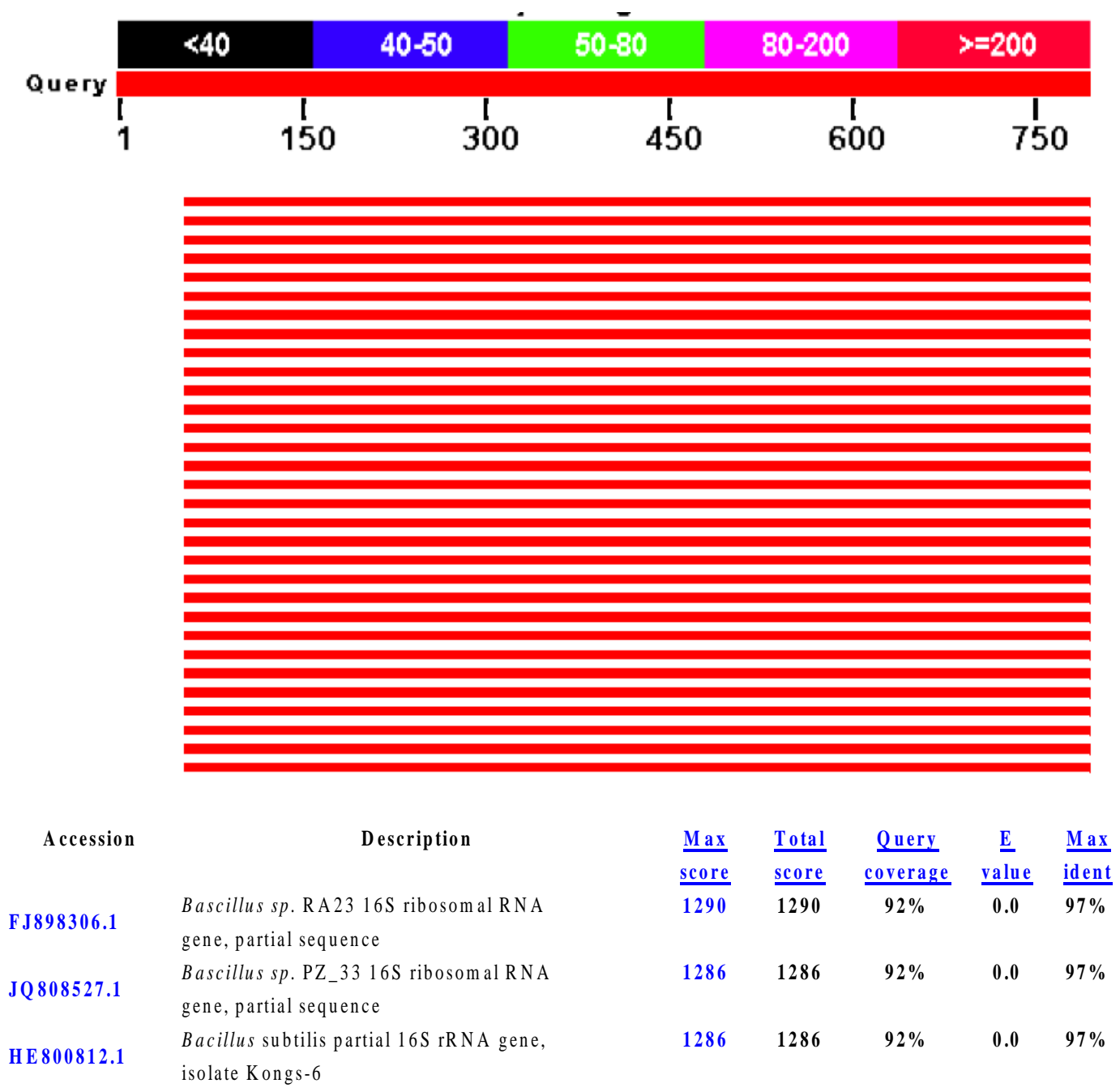

FIGURE 6. Color key for alignment scores

\subsection{Investigation of the presence of plasmid in isolated bacteria}

After the extraction of DNA by using Brinbion \& Doly method and kudo \& Liu method the DNA was electrophoresed on the $0.8 \%$ and $1 \%$ high-melting agarose gel. Ethidium bromide was used to stain the gel. The DNA bands were resumed by ultraviolet illumination (15\&16). There were here DNA bands of bacteria that were found on the agarose gel after illumination with the UV light. These bands may represent the plasmid (Fig. 7). 


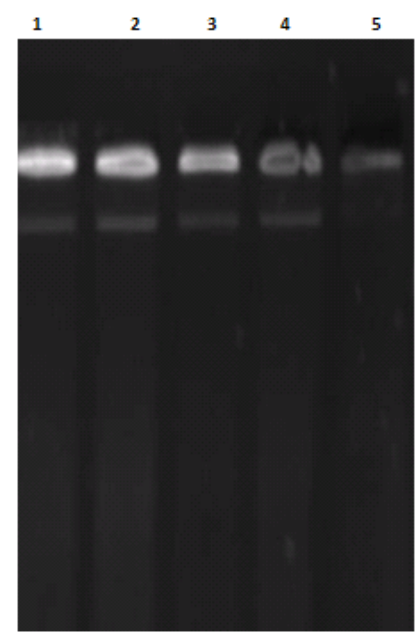

FIGURE 7. Agarose gel electrophoresis of the plasmid DNA isolated from bacterial $s p$. (lane $1,2,3 \& 4$ ). The DNA was resolved on $0.8 \%$ agarose gel and stained with ethidium bromide $(0.5 \mu \mathrm{g} / \mathrm{ml})$

\section{DISCUSSION}

The extensive pollution of natural ecosystems has occurred by organophosphorus pesticides, being used for improvement of crop production in agriculture. In this study, the sample of fenitrothion treated soil were collected and used as sources of inocula for the isolation of organisms capable of degrading the referred pesticide. Pure cultures of fenitrothion degrading bacteria were isolated by enrichment culture techniques.Rosenberg and Alexander (19) used enrichment cultures from soil and sewage to obtain bacteria able to utilize Aspon, Azodrin, Dasanit, Diazinon, Malathion, Orthene, Parathion trithion, Dimethoate, Dylox, Methyl- parathion, and Vapona. Ramanathan and Lalithakumari (20) through enrichment technique from soil also isolated Pseudomonas sp. that was able compelete mineralization of methylparathion . Also Sheela and Pai (21) used enrichment culture from soil to obtain bacteria capable of degrading fensulfothion, organophosphorus pesticide used to control the golden nematode Heterode rostochiensis.

Three types of colonies (two of them are not described) in abundance were observed on minimal medium amended with fenitrothion. When physiological and biochemical tests were done, microorganisms was found as gram-positive and non-motile (sim media) bacteria. It has been shown in the present study that isolated bacterial species can degrade fenitrothion and use it as sole source of carbon and energy. This study showed that these bacteria can successfully use Rhamnose, Mannitol, Xylose, Sucrose, etc. The isolates were identified based on morphological observation and biochemical characterization. A similar study achieved by Alonso, et al. (22) showed that two bacterial strains (Flavobacterium sp. and Arthrobacter aurescens strain) were involved in fenitrothion and it hydrolysis products (3-methyl-4-nitrophenol) degradation in laboratory condition.In the present study the identity of the isolates were however confirmed through molecular characterization. Total DNA was extracted according to the procedures described by Schmidt et al. (23) purified and used as a template for amplification of 16S rRNA gene. PCR amplification was performed with a model Gene Amp 9800 tharmal cycler using universal primers. Similarly, Kinuthia et al.(24) was identified Bascillus sp. to degrade di-chlorodi-phenyl-tri- chlorothane by 16SrRNA genRNA gene sequenching.

In the present study the growth kinetic studies showed that these bacteria can grow in $30^{\circ} \mathrm{C}$ with 7 to 8 $p H$. It was found that the optimum temperature for the growth of isolated bacteria to degrade fenitrothion is $30^{\circ} \mathrm{C}$. We also observed that if the bacteria harbour plasmid or not because the role of plasmid in the degradation of organic compounds has provided a lucrative ground for examining the potential for the mechanisms of bacterial evolution in nature and practical consequences in terms of pollution control. More research should be performed to identify the specific gene(s) that is responsible for the degradation of fenitrothion, and then the specific gene(s) can be cloned to suitable microbes to form man made colonies that will clean up an agricultural waste like fenitrothion.

Several pure bacterial isolates with the ability to use specific pesticides as a sole sourse of carbon, nitrogen or phosphorus have been isolated (25). Several other studies failed to obtain micro- organisms capable of growing on specific chemicals. However, this failure does not exclude biological involvement in degradation 
and could be attributed to the selection and composition of the liquid media under artificial environments, strains requiring special growth factors, or a major role of non-culturable microorganisms (26).

\section{ACKNOWLEDGEMENT}

We would like to thankful to the ICDDRB (Diarrhoeal Disease Research Centre, Bangladesh) for providing their lab facilities, without which this work would not have been possible. We are also thankful to Md. Fakruddin, Scientific Officer, Institute of Bangladesh Council for Scientific and Industrial Research (BCSIR) for technical assistance.

\section{REFERENCES}

[1] P.J. John, Alteration of certain blood parameters of freshwater teleost Mystus vittatus after chronic exposure to Metasystox and Sevin, Fish Physiol. and Biochem, 33, 2007, 15-20.

[2] D.E. Bahig, and D.A. Altalhi, Degradative plasmid and heavy metal resestance plasmid naturally coexist in phenol and cyanide assimilating bacteria. Am. J. Biochem. And biotechnol. 5(2), 2009, 84-93.

[3] O.E. Fagade, and E.M. Adetutu, Lead solubilization and accumulation by two stains of Pseudomonas species obtained from a battery manufacturing factory effluent. Nigeria Jour. Microbiol, 13, 1999, 39-46. (6)

[4] P. Vandevivere, and W. Verstraete, Environmental applications, in basic Biotechnology. $2^{\text {nd }}$ edition, Cambridge University Press, Cambridge, 2002, 531-557.

[5] H. Zolgharnein, M.L.M.M. Azmi, M.Z. Saad, A.R. Mutalib, and C.A.R. Mohamed, Detection of plasmids in heavy metals resestance bacteria isolated from the Persian Gulf and enclosed industrial areas. Iran. J. Biotechnol, 5, 2007, $232-239$.

[6] G.J. Tortora, B.R. Funke, and C.L. Case, Microbiology: an Introduction (Benjamin/cummings Publishing Company. California. USA, 1998), 169-176.

[7] A.O. Antoce, and L.D. Dinu,. Microbiology- principii si tehnici de laborator, Ed. Ceres, Bucuresti, 2002.

[8] H.J. Benson, Microbiological applications- A laboratory manual in general microbiology, $5^{\text {th }}$ edition, Ed. WCB, 1990.

[9] T. Vintila, and L.D. Dinu, Tehnologia produselor de biosinteza - Manual de laborator, Ed. Orizonturi Universitare, Timisoara, 2004 .

[10] C.H. Collins, P.M. Lyne, and J.M. Grange, Microbiological methods. Butterworth-Heinemann Ltd. Oxford. England. 1995 , 493.

[11] W.F. Harrigan, and M.E. McCance, Laboratory methods in food and daring microbiology. Academic, London, $1976,452$.

[12] H.W. Seeley, and P.J. Van Dermark, Microbes in action-a laboratory mannual of microbiology. Freeman, San Francisco, 1972, 361.

[13] A. Nagamani, R. Soligala, and M. Lowry, Isolation and characterization of phenol degrading Xanthobacter flavus. African Journal Biotechnology, 8(20), 2009, 5449-5453.

[14] J.F. MacFaddin, Biochemical test: identification of medical bacterial. Williams and Wilkins. London, 2000.

[15] H.C. Birnboin, and J. Doly, A rapid alkaline extraction procedure fro screening recombinant plasmid DNA. Nucleic Acid Res, 7, 1979, 1513-1523.

[16] C.I. Kudo, and S.T. Liu, Rapid procedure for detection and isolation of large and small plasmids. J. Bacteriol, 145, 1981, 13651373 .

[17] J. Sambrook, E.F. Fritsch, and T. Maniatis, Molecular Cloning : A laboratory Manual (Cold Spring Harbor Laboratory Pres. Nova York, 1989).

[18] F.E. Loffler, Q. Sun, J.R. Li, and J.M. Tiedje, 16S rRNA gene-based detection of tetrachloroethene-dechlorinating Deulfuromonas and Dehalococcoides species, App. Environ. Microbiol, 66, 2000, 1369-1374

[19] A. Rosenberg, and M. Alexander, Microbial cleavage of various organophosphorus insecticides. Appl. Environ. Microbial, 37(5), 1979, 886-91.

[20] M.P. Ramanathan, and D. Lalithakumari, Complete mineralization of methylparathion by Pseudomonas sp., A3. Appl. Biochem. Biotechnol, 80(1), 1999, 1-12.

[21] S. Sheela, S.B. Pai, Appl Environ Microbiol, 46(2), 1983, 475-479.

[22] J.L. Aloson, M.J. Sabater, I. Ibanez, M.S. Amoros, Botella, and J. Conosco, Fenitrothion and 3-methyl-4 nitrophenol degradation by two bacteria in natural waters under laboratory conditions. J. Environ. Sci. Health, 32, 1997, 799-812.

[23] T. Schmidt, C. Jung, and M. Metzlaff, Distribution and evolution of two satellite DNAs in the genes Beta vulgaris. Theoretical and applied Genetics, 82, 1991, 793-799.

[24] M.W. Kinuthia, I.B. Hamadi, W.M. Anne, K. Ciira, and K.T. Muniru, Degradation of dichlorodiphenyltrichloroethane (DDT) by bacterial isolates from cultivated and uncultivated soil. African Journal of Microbiology Research, 4(3), $2010,185-196$.

[25] B.K. Singh, and R.C. Kuhad, Biodegradation of the pesticide lindane by white- rot fungi Cyathus bulleri and Phanerochete sordida, Pest Manage sic., 56, 2000, 142-146.

[26] A. Walker, and S.J. Roberts, Degradation, Biodegradation and Enhanced Biodegradation. Proc. $9^{\text {th }}$ symp. Pesticide Chemistry: The Chemistry, mobility and degradation of xenobiotics. Italy, 1993. 